\title{
Hydro geophysical Investigation for Groundwater Development at Gbongudu Area, Akobo Ojurin, Ibadan, Southwestern Nigeria
}

\author{
${ }^{* 1}$ LAYADE, GO; ${ }^{2}$ ADEGOKE, JA; ${ }^{2}$ OLADEWA, FC \\ ${ }^{I}$ Department of Physics, Federal University of Agriculture, Abeokuta \\ ${ }^{2}$ Department of Physics, University of Ibadan, Ibadan \\ "layadeoluyinka018@gmail.com
}

\begin{abstract}
This paper presents the geophysical investigation for groundwater at Gbongudu area, Akobo Ojurin, Ibadan, Southwestern Nigeria. The area is underlain by the crystalline basement complex rocks and accessibility to potable water especially in the dry period of the year has been a major challenge. The Vertical Electrical Sounding using the Schlumberger configuration was employed. Twelve (12) vertical electrical sounding points were established in order to delineate the geo-electric layers in the area as well as evaluate the groundwater potential. The results are presented as profiles, geologic sections, curves, and maps. The VES results revealed a maximum of five geo-electric layers, viz: topsoil/lateritic sand, shale/clay, weathered layer, fractured basement and fresh basement respectively. Geo-electric sounding results were critically analyzed and interpreted. The yields of wells dug in most of these locations may be insufficient, even for domestic use because of its relatively small thicknesses. However, at a depth of $9.1 \mathrm{~m}$ a fracture zone occurs in VES 6 with resistivity value of $17.8 \Omega \mathrm{m}$ suggesting the presence of groundwater. Groundwater potential in this area is low on the average with VES 6 and VES 7 considered to be the main aquifer units suitable for groundwater exploration. ( JASEM
\end{abstract}

\section{https://dx.doi.org/10.4314/jasem.v21i3.14}

Keywords: basement complex, electrical sounding, groundwater, exploration, aquifers

Fresh water is a valuable resource for human needs and of fundamental importance to human life, animals and plants (Travassos and Menezes, 2004), it is of equal importance with the air we breathe in maintaining the virtual process to life and it makes up about $60 \%$ of body weight in human beings. Among the various sources of water, groundwater is known to be more appropriate and often meets the criteria of quality of water, the most widely used as sources of water in most African countries, Nigeria inclusive. (Fasunwon et al., 2010). Groundwater is water that has percolated downward from the surface, filling voids or open spaces in the rock formations (Osborn N.I. et al., 1998). The use of geophysics for engineering studies and groundwater exploration has increased over the last few years due to the rapid advances in computer softwares and associated numerical modeling solutions.

The electrical geophysical survey method is the detection of the surface effects produced by the electric current inside the earth. The electric techniques have been used in a wide range of geophysical investigations, permafrost mapping and geological mapping. Electrical methods are generally classified according to the energy source involved, i.e., natural methods or artificial methods (Jatau et al., 2013). Electrical resistivity technique is an effective tool in delineating areas of good potential for groundwater development (Onimisi et al., 2013). In Vertical Electrical Sounding (VES) the goal is to observe the variation of resistivity with depth. The Schlumberger configuration is most commonly used for VES investigation. The use of very low frequency electromagnetic (VLF-EM) and vertical electrical sounding (VES) for groundwater exploration is popular in the basement complex rocks terrains (Palacky et al., 1981). The electrical resistivity method has also been used extensively in groundwater investigation in the basement complex terrains (Barongo and Palacky, 1991; Olayinka and Olorunfemi, 1992; Ayolabi et al., 2004; Abiola et al., 2009; Oladapo et al., 2009). The vertical electrical sounding (VES) is a geophysical tool for the determination of subsurface geology of a place. It has been used extensively for the determination of the aquifer potential in the drilling of boreholes (Igboekwe, 2005; Igboekwe et al., 2006). McCurry (1970), who studied the geology of Zaria, has established that the Basement Complex rock is made up of the Older Granite, Biotite, and Granite-Gneiss. Farouq (2001), carried out geo-electric investigations of the groundwater potential in the Institute for Agricultural Research Farm, Samaru, Zaria, showed

*corresponding author email: "layadeoluyinka018@gmail.com 
that the thickness of the weathered basement around the area varies from $3.4 \mathrm{~m}$ to $30.4 \mathrm{~m}$ and depth to fresh basement was $40 \mathrm{~m}$.

Any elaborate groundwater development scheme in a typical basement setting requires a qualitative knowledge of hydro-geophysical parameters of the hydro-geologic units, that is, the superficial materials overlying the crystalline bedrock structures/relief (Omosuyi et al., 2003). This paper reviews basic resistivity theory affecting poor recharge of wells in the study area.

Geology And Hydrogeology of The Studied Area: The study area is Gbongudu, Akobo Ojurin, bounded approximately by latitudes $7^{0} 27^{\prime} 28^{\prime \prime}$ and $7^{\circ} 27^{\prime} 35^{\prime \prime}$ and longitudes $3^{\circ} 57^{\prime} 55^{\prime \prime}$ and $3^{\circ} 58^{\prime} 04^{\prime \prime}$ within Lagelu local government area, Southwestern, Oyo state. The area falls under the Basement Complex area of Oyo state within the southwestern part of the reactivated basement complex of Nigeria and is underlain by the crystalline basement complex which wholly belong to the Pre-Cambrian - Cambrian potentials positively (Rahman et al., 1988). The local lithological units identified in the study area comprise of Pegmatite, Quartz Vein and undifferentiated Gneiss complex probably mainly schist.

The granite gneiss is the most wide spread rock unit in the area, covering over half of the area occurring as intrusive, low-lying outcrops. Pegmatites which are intrusive igneous rocks are found in some locations and are composed of quartz, feldspar and mica, having a similar basic composition as granite. Crystal size is the most striking feature of pegmatites, with crystals usually over $5 \mathrm{~cm}$ in size. The occurrence of groundwater in crystalline rocks depends on the extent and depth of weathering and fracturing. It has a minimum elevation of $247 \mathrm{~m}$, and a maximum of $257 \mathrm{~m}$. The study area is accessible through networks of roads as shown in figure 1.

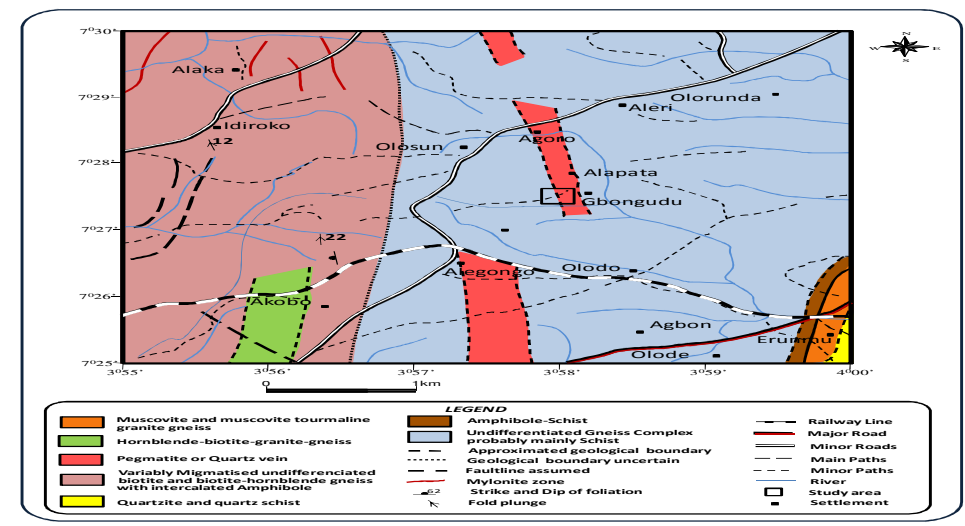

Fig 1: Geologic map showing the study area and layout (Adapted from NGSA map, 2009).

\section{MATERIALS AND METHOD}

Vertical Electrical Sounding: Schlumberger configuration: The technique is best adapted to determining depth and resistivity for flat-lying layered rock structures, such as sedimentary beds, or the depth to the water table. In this method a series of potential differences are acquired at successively greater electrode spacing while maintaining a fixed central reference point. The Schlumberger configuration is most commonly used for VES investigations. The goal is to observe the variation of resistivity with depth.

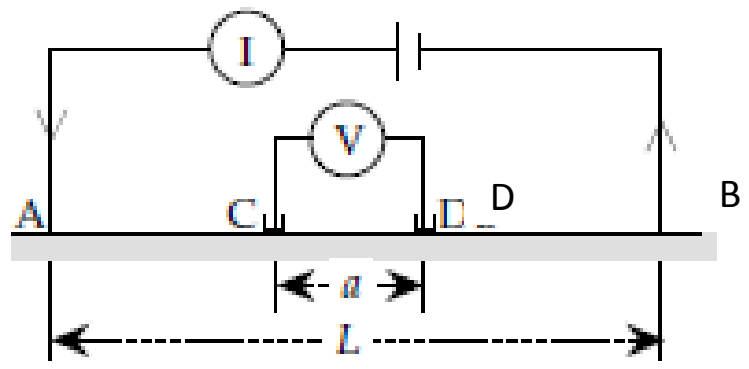

Fig 2: Schlumberger configuration for resistivity measurement, consisting of a pair of current electrodes $(\mathrm{A}, \mathrm{B})$ and a pair of potential electrodes $(\mathrm{C}, \mathrm{D})$.

LAYADE, GO; ADEGOKE, JA; OLADEWA, FC 
The mid-point of the array is kept fixed while the distance between the current electrodes is progressively increased. This causes the current lines to penetrate to even greater depths, depending on the vertical distribution of conductivity. Let the separations of the current and potential electrodes be $\mathrm{L}$ and a, respectively. Then $r_{A C}=r_{D B}=(L-a) / 2$ and $r_{A D}=r_{C B}=(L+a) / 2$. Substituting in the general formula, we get

$$
\begin{aligned}
& \rho=2 \pi \frac{V}{I}\left\{\left(\frac{2}{L-a}-\frac{2}{L-a}\right)-\left(\frac{2}{L+a}-\frac{2}{L-a}\right)\right\}^{-1} \\
& \rho=\frac{\pi}{4} \frac{V}{I}\left(\frac{L^{2}-a^{2}}{a}\right)
\end{aligned}
$$

The number of VES survey carried out was based on the interpretation of the lateral profiling as well as the length/distance of the profile the survey was to be carried out. A total of twelve VES were carried out and the results were presented as profiles, sections, curves, and maps.

Survey Techniques: The Vertical Electrical Sounding measures the vertical variations in ground apparent resistivity values with respect to a fixed center of array. The Schlumberger configuration was used to acquire VES data at twelve (12) sounding points as shown in figure 2; five along traverse one; two along traverse two, one each along traverses three and four; and three along the fifth traverse as shown in figure 3 . The electrode spacing varied from 1 to $55 \mathrm{~m}$. Current was passed into the ground through the current electrodes, and the resulting potentials were measured through the potential electrodes, and were converted to resistance, which was recorded by the resistivity meter.

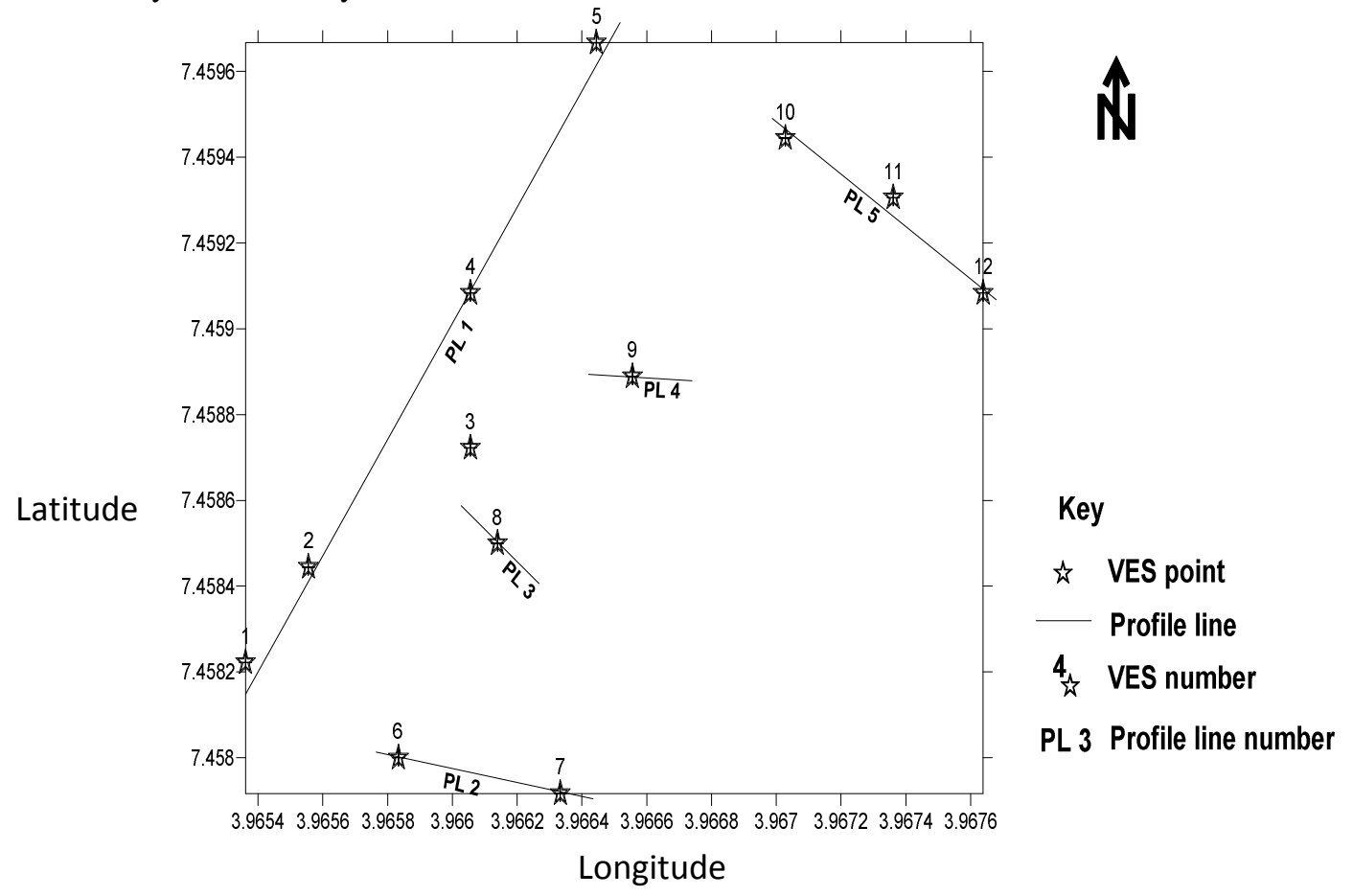

Fig 3: Base map showing the VES points

\section{RESULTS AND DISCUSSION}

The results of the VES curve obtained from the partial curve matching in figures 4-7 were then used to constrain the interpretation by the computer using iteration software known as WINRESIST. The Root Mean Square (RMS) errors for the analysis were found to be very low with an average of $2.67 \%$ (Table 1). This underscores the reliability of the analysis tool for this type of work. 
Table 1: Summary of interpreted VES curves

\begin{tabular}{|c|c|c|c|c|c|c|}
\hline $\begin{array}{c}\text { VES } \\
\text { Station }\end{array}$ & Layer Resistivity $(\mathbf{\Omega m})$ & Thickness (m) & Depth (m) & $\begin{array}{c}\text { Curve } \\
\text { Type }\end{array}$ & $\begin{array}{l}\text { RMS } \\
\text { Error }\end{array}$ & Layer Description \\
\hline 1 & $\begin{array}{c}56.8 \\
213.4 \\
4508.2\end{array}$ & $\begin{array}{c}1.3 \\
15.9\end{array}$ & $\begin{array}{c}13 \\
17.2\end{array}$ & $\mathrm{~A}$ & 2.4 & $\begin{array}{c}\text { Top Soil } \\
\text { Weathered layer } \\
\text { Fresh Basement }\end{array}$ \\
\hline 2 & $\begin{array}{c}87.5 \\
168.4 \\
1882.2\end{array}$ & $\begin{array}{l}0.8 \\
9.2\end{array}$ & $\begin{array}{l}0.8 \\
9.9\end{array}$ & A & 1.7 & $\begin{array}{c}\text { Top Soil } \\
\text { Weathered layer } \\
\text { Fresh Basement }\end{array}$ \\
\hline 3 & $\begin{array}{c}79.5 \\
279.4 \\
5996.3\end{array}$ & $\begin{array}{c}0.8 \\
11.5\end{array}$ & $\begin{array}{c}0.8 \\
12.3\end{array}$ & A & 2.0 & $\begin{array}{c}\text { Top Soil } \\
\text { Weathered layer } \\
\text { Fresh Basement }\end{array}$ \\
\hline 4 & $\begin{array}{c}144.6 \\
459.7 \\
2542.5\end{array}$ & $\begin{array}{l}0.9 \\
6.8\end{array}$ & $\begin{array}{l}0.9 \\
7.6\end{array}$ & A & 2.3 & $\begin{array}{l}\text { Top Soil/Lateritic Sand } \\
\text { Weathered Layer } \\
\text { Fresh Basement }\end{array}$ \\
\hline 5 & $\begin{array}{c}609.7 \\
135.7 \\
21065.6\end{array}$ & $\begin{array}{l}0.8 \\
2.8\end{array}$ & $\begin{array}{l}0.8 \\
3.6\end{array}$ & $\mathrm{H}$ & 3.2 & $\begin{array}{l}\text { Lateritic Sand } \\
\text { Weathered Layer } \\
\text { Fresh Basement }\end{array}$ \\
\hline 6 & $\begin{array}{c}138.4 \\
108.1 \\
17.8 \\
3876.5\end{array}$ & $\begin{array}{l}2.6 \\
6.4 \\
4.4\end{array}$ & $\begin{array}{c}2.6 \\
9.1 \\
13.5\end{array}$ & $\mathrm{QH}$ & 3.5 & $\begin{array}{l}\text { Top Soil/Lateritic Sand } \\
\text { Weathered Layer } \\
\text { Fractured Basement } \\
\text { Fresh Basement }\end{array}$ \\
\hline 7 & $\begin{array}{l}364.8 \\
63 \\
319.3 \\
633.6\end{array}$ & $\begin{array}{l}1.5 \\
2.3 \\
1.6\end{array}$ & $\begin{array}{l}1.5 \\
3.9 \\
5.5\end{array}$ & HA & 3.5 & $\begin{array}{c}\text { Top Soil/Lateritic Sand } \\
\text { Shale/Clay } \\
\text { Weathered Layer } \\
\text { Fractured Basement }\end{array}$ \\
\hline 8 & $\begin{array}{c}87.4 \\
145.4 \\
1306.1\end{array}$ & $\begin{array}{l}1.4 \\
3.4\end{array}$ & $\begin{array}{l}1.4 \\
4.8\end{array}$ & A & 2.5 & $\begin{array}{c}\text { Top Soil } \\
\text { Weathered layer } \\
\text { Fresh Basement }\end{array}$ \\
\hline 9 & $\begin{array}{c}212.2 \\
222.9 \\
1669.7\end{array}$ & $\begin{array}{l}0.4 \\
4.7\end{array}$ & $\begin{array}{l}0.4 \\
5.1\end{array}$ & A & 2.5 & $\begin{array}{l}\text { Lateritic Sand } \\
\text { Weathered Layer } \\
\text { Fresh Basement }\end{array}$ \\
\hline 10 & $\begin{array}{c}152.4 \\
58.1 \\
10147.7\end{array}$ & $\begin{array}{l}2.8 \\
4.8\end{array}$ & $\begin{array}{l}2.8 \\
7.6\end{array}$ & $\mathrm{H}$ & 2.8 & $\begin{array}{l}\text { Top Soil/Lateritic Sand } \\
\text { Weathered Layer } \\
\text { Fresh Basement }\end{array}$ \\
\hline 11 & $\begin{array}{c}114.7 \\
299.3 \\
7209.6\end{array}$ & $\begin{array}{c}0.4 \\
13.1\end{array}$ & $\begin{array}{c}0.4 \\
13.5\end{array}$ & A & 2.9 & $\begin{array}{l}\text { Top Soil/Lateritic Sand } \\
\text { Weathered Layer } \\
\text { Fresh Basement }\end{array}$ \\
\hline 12 & $\begin{array}{c}98.8 \\
153.4 \\
1228.0\end{array}$ & $\begin{array}{l}0.4 \\
6.2\end{array}$ & $\begin{array}{l}0.4 \\
6.8\end{array}$ & A & 2.6 & $\begin{array}{c}\text { Top Soil } \\
\text { Weathered Layer } \\
\text { Fresh Basement }\end{array}$ \\
\hline
\end{tabular}
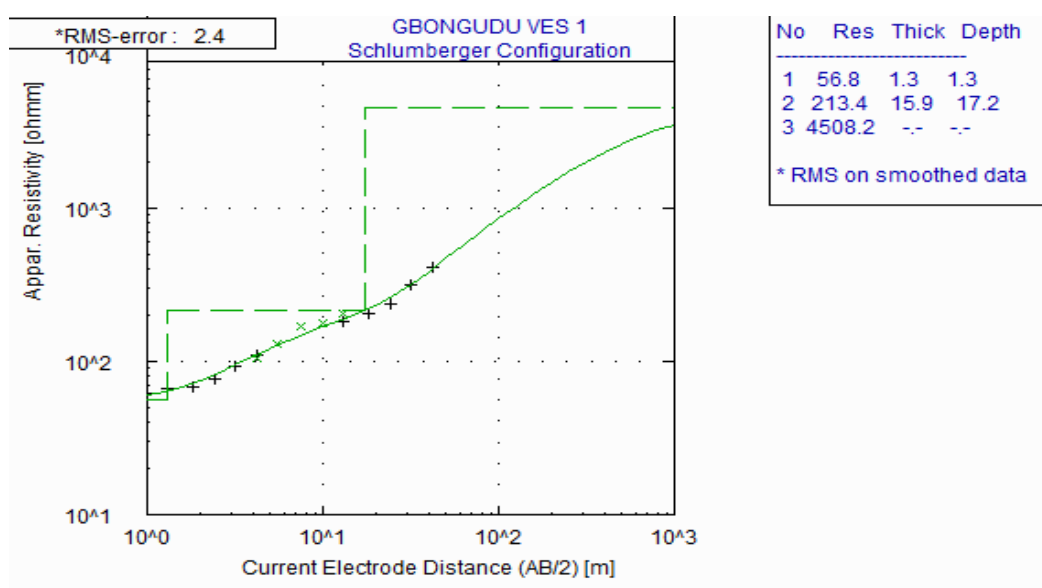

Fig 4: Typical A curve type 

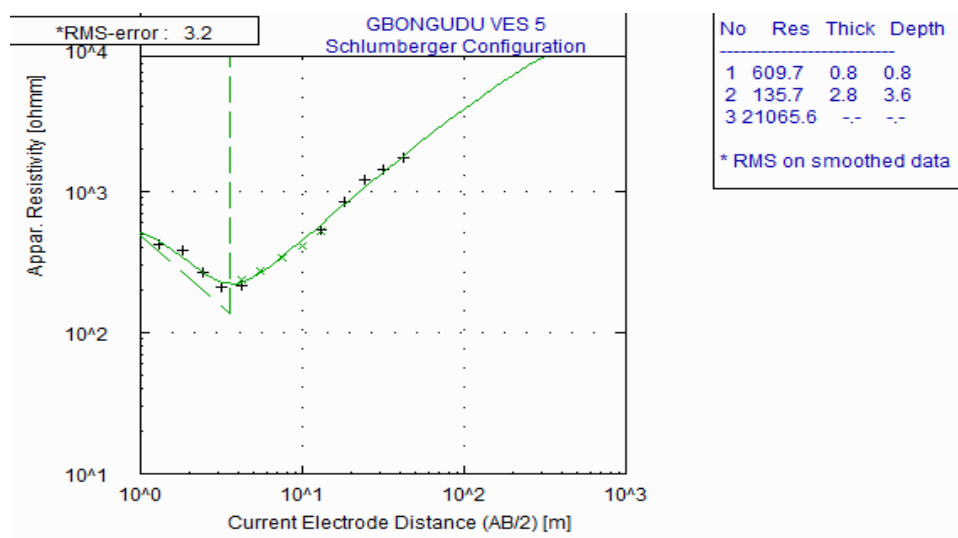

* RMS on smoothed data

Fig 5: Typical H curve type
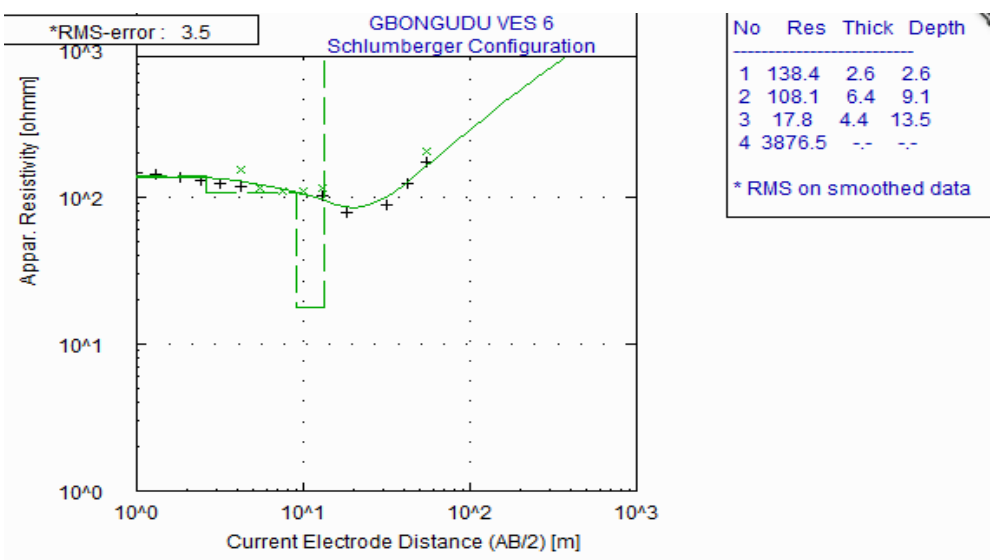

Fig 6: Typical QH curve type

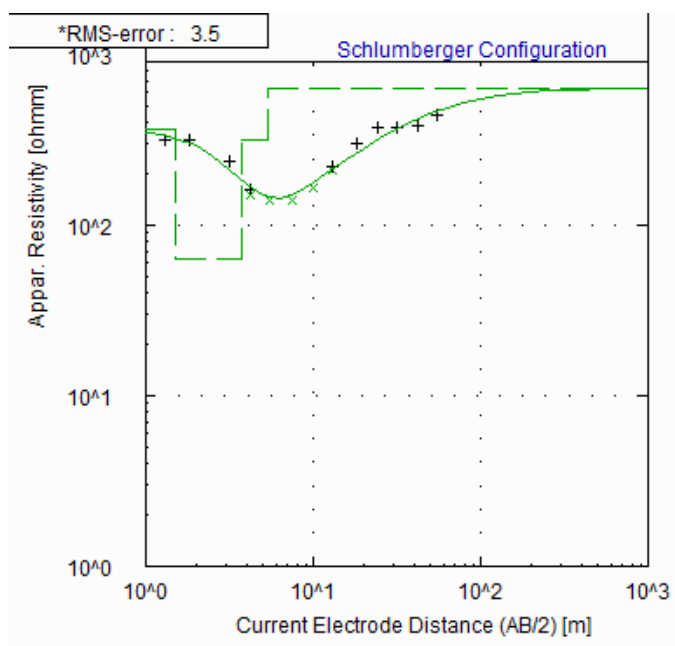

$$
\begin{array}{|lccc}
\text { No } & \text { Res } & \text { Thick } & \text { Depth } \\
\hline 1 & 364.8 & 1.5 & 1.5 \\
2 & 63.0 & 2.3 & 3.8 \\
3 & 319.3 & 1.6 & 5.4 \\
4 & 633.6 & -\because & -- \\
\text { * } &
\end{array}
$$

Fig 7: Typical HA curve type

Deductions from Curves: Profile 1: Figure 8 shows the geo-electric section for this profile which connects VES 1, 2, 3, 4 and 5. The section reveals the presence of 3 layers. The resistivity of the first layer ranges from $56.8 \Omega \mathrm{m}$ to $609.7 \Omega \mathrm{m}$ while thickness varies from $0.8 \mathrm{~m}$ to $1.3 \mathrm{~m}$. This layer constitutes the 
topsoil; the higher resistivity values suggest the presence of coarse lateritic sand. Underlying this topsoil is the weathered layer which has resistivity of $168.4 \Omega \mathrm{m}$ to $459.7 \Omega \mathrm{m}$ and thickness of $2.8 \mathrm{~m}$ to $15.9 \mathrm{~m}$. This layer overlies the bedrock with resistivity of $1882.2 \Omega \mathrm{m}$ to $21065.6 \Omega \mathrm{m}$ (tends to $\infty$ ).

Profile 2: Figure 9 shows the geo-electric section for this profile connecting two VES points, 6 and 7. It reveals the presence of four to five layers. The first layer is the topsoil/lateritic sand, its resistivity values are 138.4 $\Omega \mathrm{m}$ and $364.8 \Omega \mathrm{m}$ for VES 6 and VES 7 respectively. Underlying the topsoil is the weathered layer. In VES 7 the weathered layer is made up of shale/clay and sandy clay because of its resistivity values of $63 \Omega \mathrm{m}$ and $319.3 \Omega \mathrm{m}$. The weathered layer of VES 6 has resistivity and thickness of $108.1 \Omega \mathrm{m}$ and $6.4 \mathrm{~m}$. beyond this layer is fresh bedrock of resistivity of $3876.5 \Omega \mathrm{m}$.

Profiles 3 and 4: The geo-electric sections for these profiles only connect one VES point each; VES 8 and 9 respectively. Figure 10 and 11 shows the geoelectric section for profiles 3 and 4 respectively. The sections reveal the presence of 3 layers each. The resistivity values of the first layer are $87.4 \Omega \mathrm{m}$ and $212.2 \Omega \mathrm{m}$ with thicknesses of $1.4 \mathrm{~m}$ to $0.4 \mathrm{~m}$ for VES 8 and 9 respectively. This layer constitutes the topsoil; suggesting a composition of lateritic sand. Underlying this topsoil is the weathered layer which has resistivity values of $145.4 \Omega \mathrm{m}$ and $222.9 \Omega \mathrm{m}$ with thicknesses of 4.8 and $5.1 \mathrm{~m}$ for VES 8 and 9 respectively. This layer overlies the bedrock with resistivity of $1306.1 \Omega \mathrm{m}$ to $1669.7 \Omega \mathrm{m}$ for VES 8 and 9 respectively.
Profile 5: Figure 12 shows the geo-electric section for this profile connecting VES 10, 11 and 12. The section also reveals the presence of 3 layers. The resistivity of the first layer ranges from $98.2 \Omega \mathrm{m}$ to $152.4 \Omega \mathrm{m}$ (over $100 \Omega \mathrm{m}$ on an average) while thickness varies from $0.4 \mathrm{~m}$ to $4.8 \mathrm{~m}$. This layer constitutes the topsoil. Underlying this topsoil is the weathered layer which has resistivity of $58.1 \Omega \mathrm{m}$ to $299.3 \Omega \mathrm{m}$ and thickness of $2.8 \mathrm{~m}$ to $13.1 \mathrm{~m}$. This layer overlies the bedrock with resistivity of 1228 $\Omega \mathrm{m}$ to $10147.7 \Omega \mathrm{m}$ (tends to $\infty$ ).

Groundwater Prospect Evaluation: The weathered layer may serve as a minor aquifer, although the recharge may be low due to the low and moderate porosity and permeability of the layer. The yields of wells dug in most of these locations (VES 4, 5, 8, 9 and 12) may be insufficient, even for domestic use because of its relatively small thicknesses $(6.8 \mathrm{~m}, 2.8$ $\mathrm{m}, 3.4 \mathrm{~m}, 4.7 \mathrm{~m}$ and $6.2 \mathrm{~m}$ respectively). However VES 1, VES 2, VES 3 and VES 11 may be moderately sufficient because of its appreciable thickness of $15.9 \mathrm{~m}, 9.2 \mathrm{~m}, 11.5 \mathrm{~m}$ and $13.1 \mathrm{~m}$ and resistivity values of $213.4 \Omega \mathrm{m}, 168.4 \Omega \mathrm{m}, 279.4 \Omega \mathrm{m}$ and $299.3 \Omega \mathrm{m}$ respectively. At a depth of $9.1 \mathrm{~m}$ a fracture zone occurs in VES 6 with resistivity value of $17.8 \Omega \mathrm{m}$ suggesting the presence of groundwater; this zone is the main aquifer unit in this area. For VES 7 which is an extension from VES 6, the higher resistivity value of $319.3 \Omega \mathrm{m}$ suggests that the recharge may be very low due to the low porosity and permeability of the second layer (clay/shale). The unconsolidated materials overlying the crystalline basement ranging from $3.6 \mathrm{~m}$ to $17.3 \mathrm{~m}$ in Gbongudu suggesting that the water bearing horizon across the area is low.

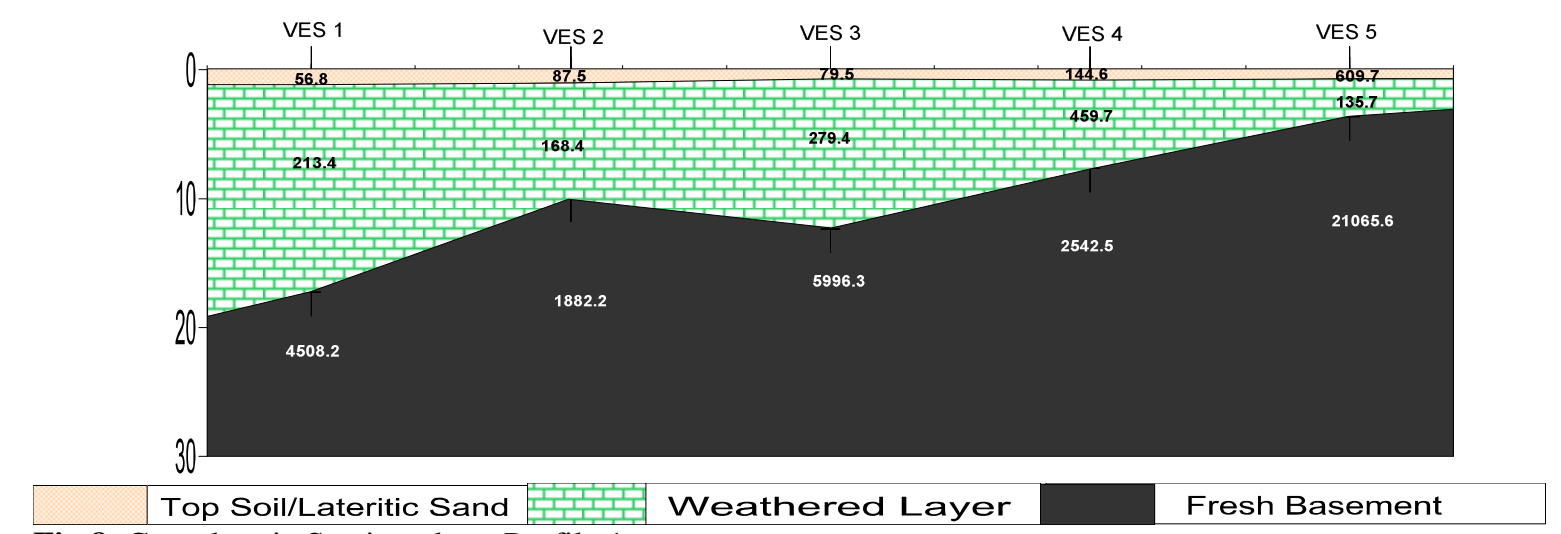

Fig 8: Geo-electric Section along Profile 1 


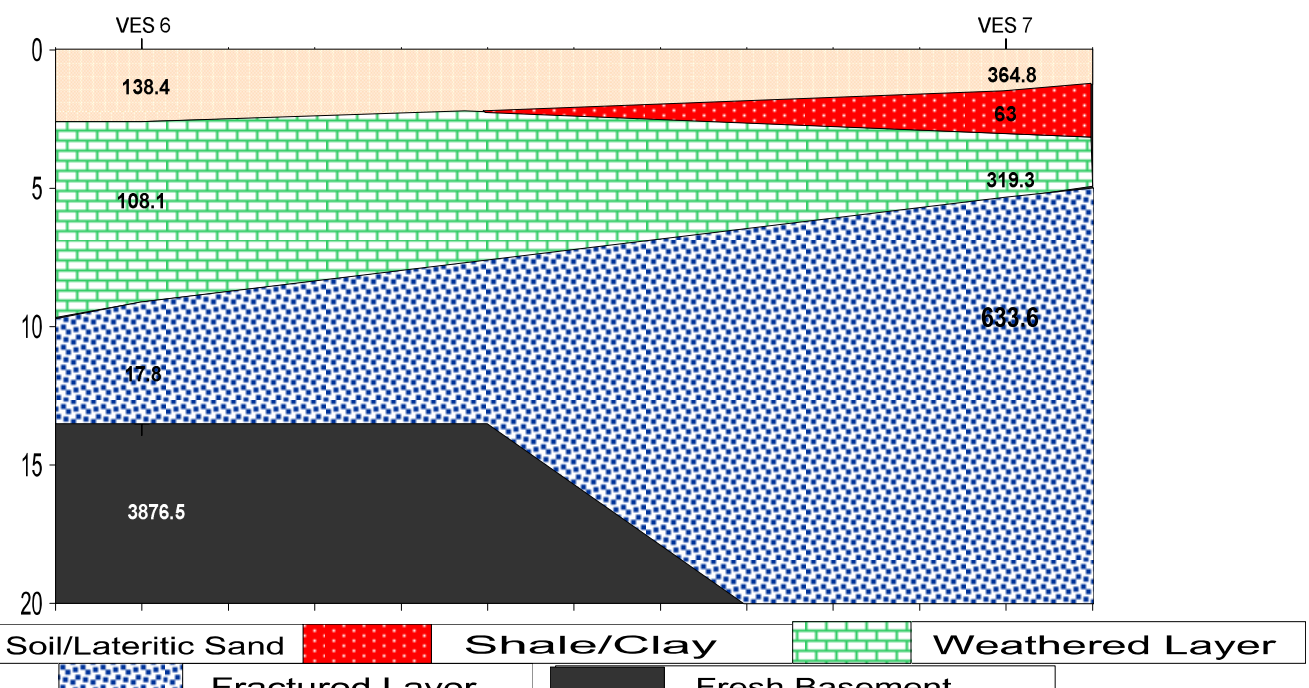
W. Fractured Layer Fresh Basement

Fig 9: Geo-electric Section along Profile 2

VES 8

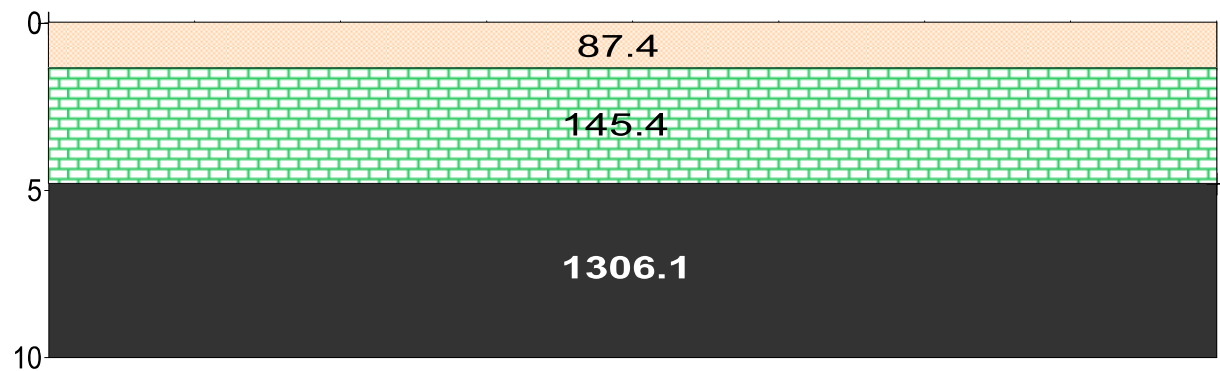

Top Soil/Lateritic Sand $\quad$ Feathered Layer $\quad$ Fresh Basement

Fig 10: Geo-electric Section along Profile 3

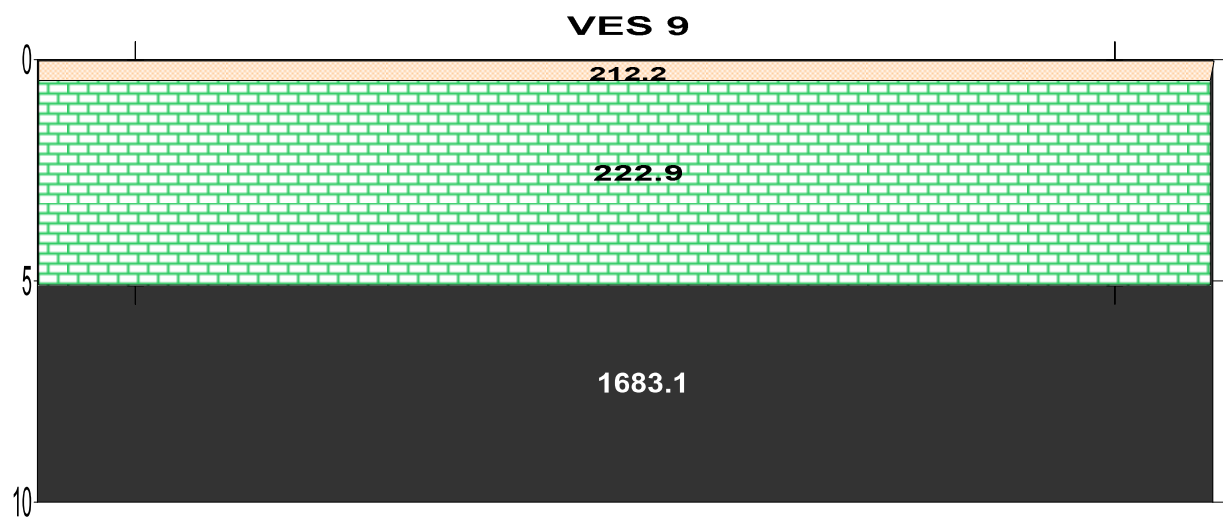

Top Soil/Lateritic Sand Weathered Layer

Fig 11: Geo-electric Section, Profile 4

Fresh Basement 


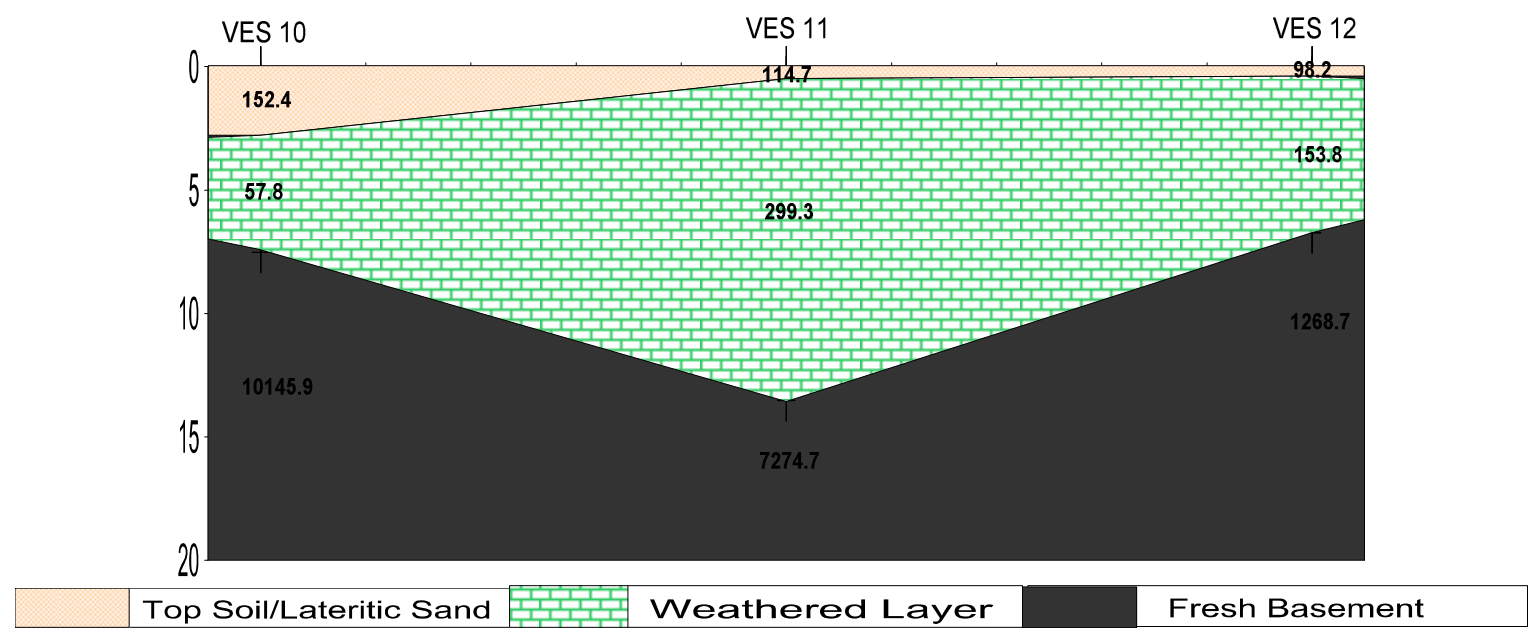

Fig 12: Geo-electric Sectioning, Profile 5

Conclusion: A geophysical investigation of Gbongudu area of Akobo Ojurin has identified zones of moderate and low groundwater potentials with five major geologic formations. These are topsoil/lateritic sand, shale/clay, weathered layer, fractured basement and fresh basement. The unconsolidated materials overlying the crystalline basement rocks around the area constitute the major water-bearing horizon from which the inhabitants abstract water through hangdug wells for their domestic needs.

The yields of wells dug in most of these locations may be insufficient, due to small thicknesses, however at a depth of $9.1 \mathrm{~m}$ a fracture zone occurs with resistivity value of $17.8 \Omega \mathrm{m}$ suggesting the presence of groundwater. This geologic layer is characterized by structural features like fractures, fissures or pore spaces that enhance groundwater permeability and storage. This zone is the main aquifer unit in this area and are recommended for groundwater exploration.

\section{REFERENCES}

Abiola O, Enikanselu PA, Oladapo MI (2009). Groundwater potential and aquifer protective capacity of overburden units in Ado-Ekiti, southwestern Nigeria. Int. J. Phys. Sci. 4(3):120132.

Ayolabi EA, Adedeji JK, Oladapo MI (2004). A geoelectric mapping of Ijapo Akure southwest Nigeria and its hydrogeological implications. Global J. Pure. Appl. Sci. 10(3):441-446.

Bala AE, Ike EC (2001). The Aquifer of the Crystalline Basement Rocks in Gusau Area, North-Western Nigeria. J. Mining Geol., 37(2): 177- 184.
Barongo JO, Palacky GJ (1991). Investigations of electrical properties of weathered layer in the Yala area, western Kenya, using resistivity soundings. Geophysics 56(1):133-138.

Farouq, A.U. (2001). Geoelectric Investigation of the Groundwater Potential in the Institute for Agricultural Research Farm. Unpublished M. Sc. Thesis, Department of Physics, Ahmadu Bello University, Zaria.

Fasunwon O.O., Ayeni A.O., Lawal A.O., 2010. A Comparative Study of Borehole Water Quality From Sedimentary Terrain And Basement Complex In South-Western, Nigeria. Research Journal of Environmental Sciences, 4: 327-335

Igboekwe, M.U. (2005). Geoelectrical exploration for groundwater potentials in Abia State, Nigeria. Unpublished Ph.D Thesis. Michael Opara University of Agriculture; Umidike, Nigeria. 131

Igboekwe, M. U., Okwueze, E. E., and Okereke C. S. (2006). Delineation of Potential Aquifer zones from Geoelectric Soundings in Akwa Ibom River Watershed, Southwestern Nigeria: Journal of Engineering and Applied Science. 1(4): 410-421

Jatau, B.S., Patrick N.O., Baba A., Fadele S.I. (Jan 2013): The Use of Vertical Electrical Sounding (VES) for Subsurface Geophysical Investigation around Bomo Area, kaduna State, Nigeria. IOSR Journal of Engineering (IOSRJEN). Vol 3, Issue 1, V4 PP 10-15 
McCurry, P. (1970). The Geology of Zaria Sheet 21. Unpublished M.Sc. Thesis, Department of Geology, Ahmadu Bello University, Zaria.

Nigerian Geological Survey Agency NGSA Map, 2009.

Oladapo MI, Adeoye-Oladapo OO, Mogaji KA (2009) Hydrogeophysical Study of the Groundwater Potential of Ilara-Mokin southwestern Nigeria. Global J. Pure. Appl. Sci. 15(2):195-204.

Olayinka AI, Olorunfemi MO (1992). Determination of geoelectrical characteristics in Okene area and implication for Borehole sitting. J. Mining Geol. 28(2):403-412.

Omosuyi, G.O., Ojo, J.S., and Olorunfem, M.O. 1998. Geoelectric Sounding to Delineate Shallow Aquifers in the Coastal Plain Sands of Okitipupa Area, Southwestern Nigeria. The Pacific Journal of Science and Technology. Vol 9(2):562-577.
Onimisi M., Daniel A. and Kolawole M.S. (2013). Vertical Electrical Sounding Investigation for Delineation of Geoelectric Layers and Evaluation of Groundwater Potential in Ajagba, Asa and Ikonofin Localities of Ola Oluwa Local Government Area of Osun State, South Western Nigeria. Research Journal of Applied Sciences, Engineering and Technology 6(18): 3324-3331, 2013

Osborn, N.I., Eckenstein, E. and Koon, K.Q. (1998).Vulnerability Assessment of Twelve Major Aquifers in Oklahoma; Oklahoma Water Resources Board Technical Report. 98-5

Palacky GJ, Ritsema IR, Dejong SJ (1981). Electromagnetic Prospecting for Groundwater in Precambrian Terrains in the Republic of Upper Volta. Geophysical Prospecting, pp. 932-955.

Rahman AMS, Ekwere SJ, Azmatullah M, Ukpong E.E. (1988), Petrology and Geochemistry of Granitic Intrusive'E' Rocks from the Western Part of Oban Massif, Southeastern Nigeria. Journal of African Earth Science; 7: 149-159

Travassos Jandyr de Menezes, Menezes Paulo de Tarso de Tarso Luiz (2004). GPR exploration for groundwater in a crystalline rock terrain. Journal of Applied Geophysics. 55: 239-248 